Article

\title{
Determination of Strength Properties of Energy Plants on the Example of Miscanthus $\times$ Giganteus, Rosa Multiflora and Salix Viminalis
}

\author{
Monika Słupska *, Arkadiusz Dyjakon *(D) and Roman Stopa \\ Institute of Agricultural Engineering, Wroclaw University of Environmental and Life Sciences, 51-630 Wroclaw, \\ Poland; roman.stopa@upwr.edu.pl \\ * Correspondence: monika.slupska.95@gmail.com (M.S.); arkadiusz.dyjakon@upwr.edu.pl (A.D.); \\ Tel.: +48-785-052-155 (M.S.); +48-71-320-5945 (A.D.)
}

Received: 16 August 2019; Accepted: 24 September 2019; Published: 25 September 2019

check for updates

\begin{abstract}
Energy from biomass accounts for $70 \%$ of all renewables used for heat and electricity production. Such a significant share of biomass determines the need for the investigation of their mechanical properties, as most of the lignocellulosic material requires cutting, chipping or milling before its utilization for energy purposes. Therefore, the knowledge about cutting resistance, bending stiffness, and impact strength of the energy plants is very important. The values of these parameters are used in the proper selection of shredding machines and their elements, wrapping nets or determination of power demand during raw material conversion. This paper presents the results of research on the mechanical properties of selected energy plants. The scope of the research included three different plant species: Miscanthus $\times$ giganteus, Rosa multiflora, and Salix viminalis, investigated in terms of cutting resistance, bending stiffness and impact strength of stalks. The results showed that the average stalk cutting resistance for the rotation speed of 4200 RPM was $0.17 \mathrm{~N} \cdot \mathrm{mm}^{-2}$ for the Miscanthus $\times$ giganteus, $0.15 \mathrm{~N} \cdot \mathrm{mm}^{-2}$ for the Rosa multiflora and $0.2 \mathrm{~N} \cdot \mathrm{mm}^{-2}$ for the Salix viminalis. Meanwhile, for a rotation speed of 3200 RPM, the cutting resistance amounted to $0.15 \mathrm{~N} \cdot \mathrm{mm}^{-2}$ for Miscanthus $\times$ giganteus, $0.16 \mathrm{~N} \cdot \mathrm{mm}^{-2}$ for Rosa multiflora and $0.18 \mathrm{~N} \cdot \mathrm{mm}^{-2}$ for Salix viminalis. For the impact measurements, the Salix viminalis exceeded $40 \mathrm{~J} \cdot \mathrm{mm}^{-2}$ of absorbed energy. Meanwhile, the average impact strength value for the Rosa multiflora was $0.53 \mathrm{~J} \cdot \mathrm{mm}^{-2}$ and for the Miscanthus $\times$ giganteus was $0.22 \mathrm{~J} \cdot \mathrm{mm}^{-2}$. The bending stiffness of Miscanthus $\times$ giganteus at an average modulus of $3.44 \mathrm{GPa}$ was $1.1 \mathrm{~N} \cdot \mathrm{m}^{2}$ for the basal zone, $0.78 \mathrm{~N} \cdot \mathrm{m}^{2}$ for the central zone, and $0.72 \mathrm{~N} \cdot \mathrm{m}^{2}$ of the apical zone. For the average Young's modulus of $0.19 \mathrm{GPa}$, the bending stiffness of the Rosa multiflora reached a value of $0.64 \mathrm{~N} \cdot \mathrm{m}^{2}$ for the basal zone, $0.23 \mathrm{~N} \cdot \mathrm{m}^{2}$ for the central zone, and $0.28 \mathrm{~N} \cdot \mathrm{m}^{2}$ for the apical zone. The Salix viminalis, with an average modulus of elasticity of $0.23 \mathrm{GPa}$, achieved bending stiffness in the basal zone of $0.99 \mathrm{~N} \cdot \mathrm{m}^{2}$, the central zone $0.33 \mathrm{~N} \cdot \mathrm{m}^{2}$, and the tip zone $0.38 \mathrm{~N} \cdot \mathrm{m}^{2}$. This research makes it possible to expand our knowledge in the field of biomass processing and construction of agricultural machinery with higher processing efficiency.
\end{abstract}

Keywords: energy crops; cutting resistance; impact strength test; Young's modulus

\section{Introduction}

According to the Global Bioenergy Statistics (2018), biomass accounts for 70\% of the total primary energy supply of all renewables; moreover, it accounts for $95.9 \%$ of heat generation derived from renewables [1]. The use of biomass for energy purposes supports the reduction of carbon dioxide emissions and is in line with the strategy adopted by the European Union [2,3]. Biomass has already attracted attention from the fuel market in the context of controlling greenhouse gas emissions [4]. 
Also, the increase in wood prices, caused by the increased demand of paper, cellulose and power engineering, has enabled the use of crop and waste biomass as an alternative for the world's growing needs [5]. Moreover, intensification of biomass production in the form of energy crops may reduce the overproduction of food encountered in agriculture as well as contribute to the improvement of the environment by following the Common Agricultural Policy (CAP) adopted rules [6]. For this reason, energy crops are recognized as a key source of renewable energy with high potential in the coming future, especially in Europe [7].

Currently, energy crops still represent a small part of the total biomass production. Bioenergy Europe [8] estimated their area at 117401 ha, which is $0.03 \%$ of arable land in the EU28 [8,9]. As a result, the energy potential of selected energy crops amounts to 13,893.9 GJ per year (Table 1).

Table 1. The energy potential of selected energy crops in EU28.

\begin{tabular}{lcccc}
\hline & Arable Land & Yield & HHV & Energy Potential \\
\cline { 2 - 5 } & ha & $\mathbf{M g}_{\text {d.m. }} \cdot \mathbf{h a}$ & $\mathbf{M J} \cdot \mathbf{k g}^{\mathbf{- 1}}$ & $\mathbf{G J}^{\mathbf{1}} \cdot \mathbf{y r}^{\mathbf{- 1}}$ \\
\hline Miscanthus $\times$ giganteus & $24.62[8]$ & $18.10[10]$ & $19.20[11]$ & 8555.94 \\
Salix viminalis & $19.38[8]$ & $14.60[12]$ & $18.60[11]$ & 5334.38 \\
Rosa multiflora & $0.10[8,13]$ & $2.05[13]$ & $17.12[14]$ & 3.58 \\
\hline
\end{tabular}

The European Union, with respect to environmental protection, encourages countries to introduce energy crops [15]. The harvested biomass coming from energy crops can be easily converted into a valuable form for the energy market. The most popular conversion methods are chipping, baling, briquetting or pelleting. The choice of method depends mainly on the market demand and needs of the final user/consumer. In the case of chipping, it is important to properly match both the cutting elements and the parameters of the chipping device. About $50 \%$ of energy is absorbed by forage harvester for shredding biomass material. The following plant parameters affect the grinding process: moisture, hardness, stiffness, compactness, structure, and coefficient of friction [16,17]. Additionally, the appropriate selection of biomass processing machines and methods can increase the efficiency of processing, reduce the risk of the failures, and reduce the consumption of energy and raw materials. Therefore, proper examination of the processed material allows the selection of the process, as well as the components and materials, that build the machine. For this purpose, it is necessary to determine the strength parameters of the grinding material [18-22]. Some of the most common methods for testing the strength properties of plants are bending stiffness, impact resistance and determination of destructive stresses, including shearing stresses [23].

Until now, the impact strength of energy plants has not been measured using the Charpy method, which is described in detail in the PN-EN ISO 148-1: 2017-02 standard [24]. Thanks to the Charpy test, it is possible to adjust the appropriate method of grinding biomass and possible elimination of some agricultural treatments that might not bring the expected results. Skubisz et al. [25], Woliński et al. [26], and Prasada [27] have measured stalk shear energy by the impact method using a knife blade as a tool that causes an impact in a Charpy's impact test stand. Moreover, the measurement method concerned individual samples and assumed the constant speed of the blade forced by its free fall. Furthermore, Lisowski et al. [28], Fraczek et al. [29], Chen et al. [30] and Chattopadhyay et al. [31] studied the cutting energy of stalks of Sorghum, Hemps, Jerusalem artichokes, and Miscanthus $\times$ giganteus, accordingly. Yore et al. [32] determined the cutting energy for rice straw at a cutting speed of 500 strokes per minute. The authors performed the tests for one, two and five stems, and concluded that as the number of cut stalks (the cross-section) increases, the unit energy absorbed per cut decreases (concerning one stalk).

Igathinathane et al. [33] checked the force needed to cut the corn stalk depending on its orientation with the blade. Azadbakht [34] investigated the dependence of canola stalk cutting energy on moisture content and cutting height. However, the tests were performed only in quasi-static conditions. 
Nowakowski et al. [35] conducted research related to the modulus of elasticity of selected energetic plants, including Miscanthus $\times$ giganteus, Salix viminalis, and Rosa multiflora. However, no data concerning stiffness on the bending of the stalks, or the relationship between the measurement zones, diameter, and bending power during the bending test, were presented. Such measurements, for example, may allow the selection of a sufficiently durable net wrapping the plant bale. Kronbergs [22] examined the ultimate tensile, the shear strength, the modulus of elasticity, the shear modulus, and the energy demand for compacting and pressing of wheat stalks. Mathanker et al. [36] investigated the cutting energy of energy cane at different speeds and stalk orientation relative to the blade.

As a result, in the literature, there are limited data about the strength and cutting resistance at variable speeds of selected energy plants. Moreover, no information was found about energy crops with respect to their bending stiffness and the relations between the cross-sectional surface, the speed of quasi-static load, bending force and displacement. Therefore, for a more extensive plant survey that can be used to improve the current state of the agricultural technology, this work aimed to examine the resistance of selected energy plants to cut stalks at variable rotation speeds, as well as to determine their impact strength and rigidity for bending.

\section{Materials and Methods}

\subsection{Materials Used in the Experiments}

In the tests, the following annual biomass stalks from energy crops were used (Figure 1): Miscanthus $\times$ giganteus, Rosa multiflora, and Salix viminalis. Salix viminalis is a perennial woody crop, Miscanthus $\times$ giganteus is a perennial herbaceous C4 crop, whereas Rosa multiflora of the Jatar cultivar is a perennial shrub that is usually harvested in two-year rotations. These plants are characterized by resistance to moderately cold climate and drought. Therefore, they are most common in the countries of Western-Northern Europe. In this climate, Rosa multiflora grows in the wild and has relatively low soil requirements. It tolerates drought and low temperatures, as well as being resistant to pathogens. Additionally, the high calorific value of this crop makes it suitable for utilization as an energy source in power plants. Miscanthus $\times$ giganteus and Salix viminalis have low soil requirements and are characterized by fast growth; therefore, they are used not only for energy purposes, but also as raw materials [37].

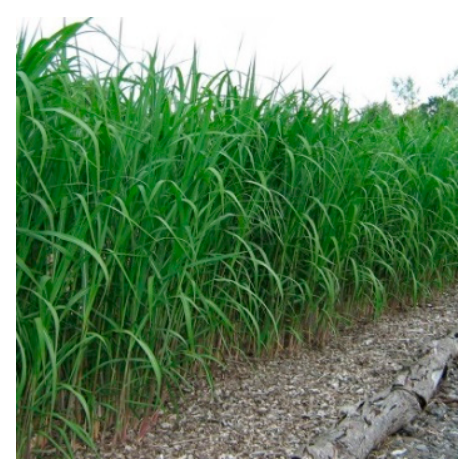

(a) Miscanthus $\times$ giganteus

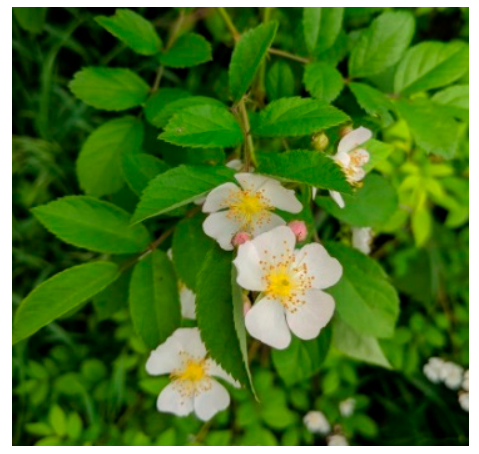

(b) Rosa multiflora

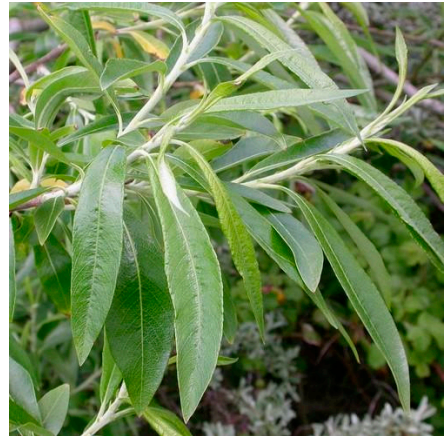

(c) Salix viminalis

Figure 1. Biomass investigated in the study.

The biomass was obtained from the one-year cultivation of energy crops belonging to the Wroclaw University of Environmental and Life Sciences in March 2019.

The range of the sample diameters was as follows: $5.71-10.87 \mathrm{~mm}$ for Miscanthus $\times$ giganteus, $2.60-11.80 \mathrm{~mm}$ for Rosa multiflora and 3.10-13.25 mm for Salix viminalis. Due to the different strength properties of individual plant parts, and the large differences in diameters along the plant, rigidity testing was performed after the division of the plant stalks into three measuring parts (zones): basal, middle and apical. The measuring zones were $0.3 \mathrm{~m}$ long. The basal zone was taken along the length from the 
cutting place to the designated measuring length, the middle zone was determined from the center of the plant after 0.15 meters towards the basal and apical zone, and the apical zone was taken from the top of the plant according to the determined measuring length.

\subsection{Proximate Analysis of Biomass}

To characterize the investigated biomass, proximate analysis was performed. The samples of a randomly collected portion of each biomass $(1500 \mathrm{~g})$ were collected, dried and ground in the laboratory mill LMN 100 (Testchem, Pszów, Poland) to the fraction below $1 \mathrm{~mm}$. From the obtained pulverized material, the required samples (in accordance with the applied ISO Standards) for further analyzes were used, accordingly. The proximate analysis included parameters such as moisture content (MC), higher heating value (HHV), lower heating value (LHV), ash content (AC), and volatile matter content (VM).

The moisture content was determined according to PN-EN ISO 18134-2:2017-03E [38] using a laboratory moisture analyzer SARTORIUS MA150 (Sartorius, Goettingen, Germany). The higher heating value (HHV) was determined in a calorimetric bomb IKA C200 (IKA, Lucknow, India) in accordance with PN-EN ISO 18125:2017-07 [39]. Next, the lower heating value (LHV) was calculated as a function of the higher heating value (HHV) and moisture content in the biomass according to [40].

$$
\mathrm{LHV}=\mathrm{HHV} \times(1-\mathrm{MC})-\mathrm{r} \times \mathrm{MC}
$$

where $\mathrm{HHV}$ is the higher heating value $\left(\mathrm{MJ} \cdot \mathrm{kg}^{-1}\right), \mathrm{MC}$ is moisture content, and $\mathrm{r}$ is the latent heat of water vaporization $\left(\mathrm{r}=2.44 \mathrm{MJ} \cdot \mathrm{kg}^{-1}\right)$.

Ash content in biomass was determined according to PN ISO 1171:2010 [41] using the muffle furnace SNOL 8.2/1100 (SNOL, Utena, Lithuania). The volatile matter content (VM) in the biomass was determined according to PN-EN ISO 18123:2016-01 [42].

\subsection{Procedure of the Cutting Resistance Test}

The research device (Figure 2), for cutting resistance measurements, was designed and constructed in the Department of Fundamentals of Technology at the Wroclaw University of Environmental and Life Sciences. The cutting resistance tests were carried out for three different initial rotation speeds of the chopper, successively: 4200, 3200 and 2200 RPM. The power of the engine was $2.5 \mathrm{~kW}$. A laser DT-2236 (Lutron Electronics Company, Coopersburg, Pennsylvania, United States) was used to measure the rotation speed with an accuracy of 1 RPM. Torque measurements were carried out using an 8652-6001 torque sensor (Burster GmbH \& Co. KG, Gernsbach, Germany). The diameter of each sample was measured with a caliper DC-1 (Ovibell GmbH \& Co. KG, Mulheim, Germany), and then the shear surface was determined.

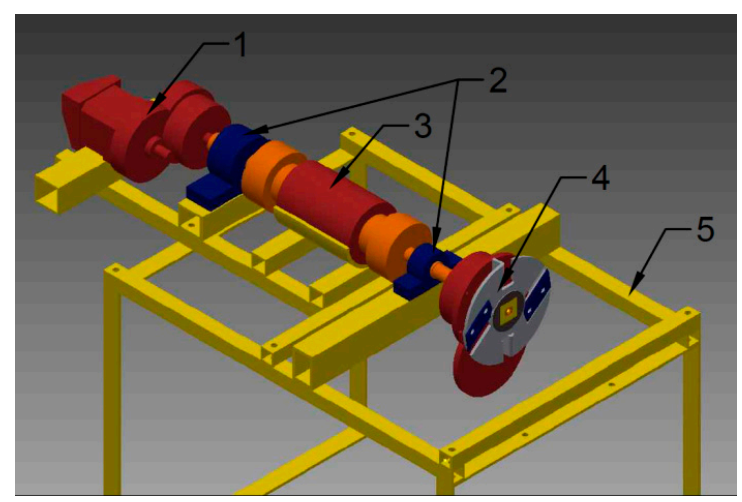

Figure 2. Design of a device for measuring the resistance of cutting stalks: 1—electric motor, 2-bearing, 3 -torque gauge, 4-cutting set, 5-frame. 
The cutting resistance was determined as follows:

$$
\mathrm{F}=\frac{\tau}{\mathrm{L}}
$$

where $\mathrm{F}$ is the cutting force $(\mathrm{N}), \tau$ is the torque during cutting, $\mathrm{L}$ is the position vector of force $(66 \mathrm{~mm})$.

$$
\mathrm{CR}=\frac{\mathrm{F}}{\mathrm{A}}
$$

where $\mathrm{CR}$ is the cutting resistance $\left(\mathrm{N} \cdot \mathrm{mm}^{-2}\right), \mathrm{A}$ is the cutting surface $\left(\mathrm{mm}^{2}\right)$.

\subsection{Procedure of the Bending Stiffness Test}

The bending test was performed according to the PN-EN 310:1994 standard [43]. Due to the differences in the diameter of individual parts of the material, the biomass stalks were divided into three measurement parts (zones): basal (1), middle (2) and apical (3), as shown in Figure 3.
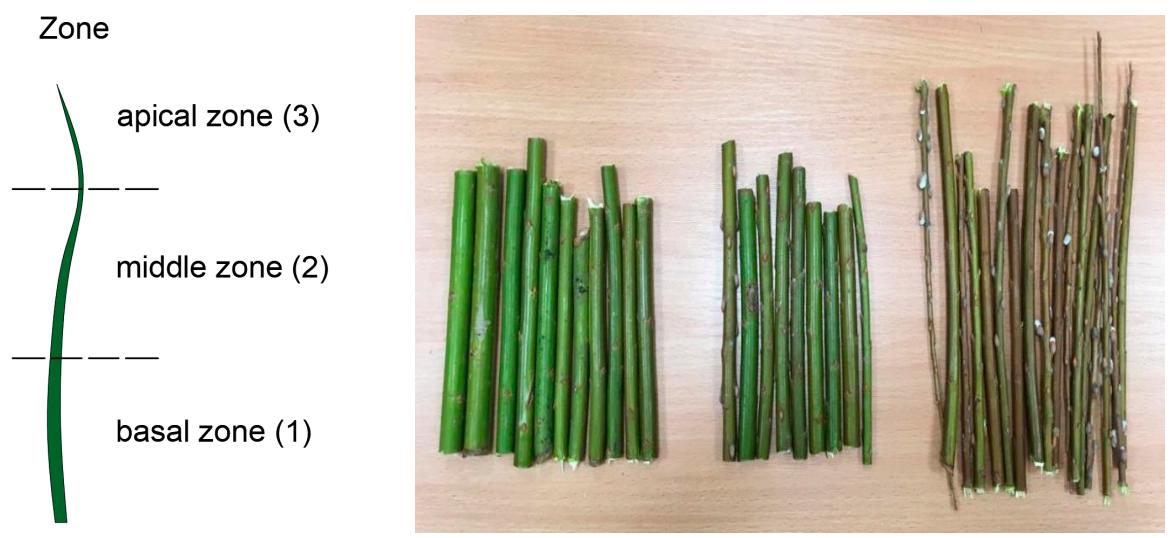

Figure 3. The zones of biomass material.

Before each measurement, the diameter of the sample was measured to determine the moment of inertia and the bending index. The prepared samples were subjected to a bending load using the Instron 5566 (Instron, Norwood, Massachusetts, United States) (Figure 4) with a measuring range up to $1 \mathrm{kN}$. The measuring stand consisted of a head equipped with a sample loading attachment in its central point and a bottom plate, to which an element constituting two-point support for the material subjected to bending test was fixed.

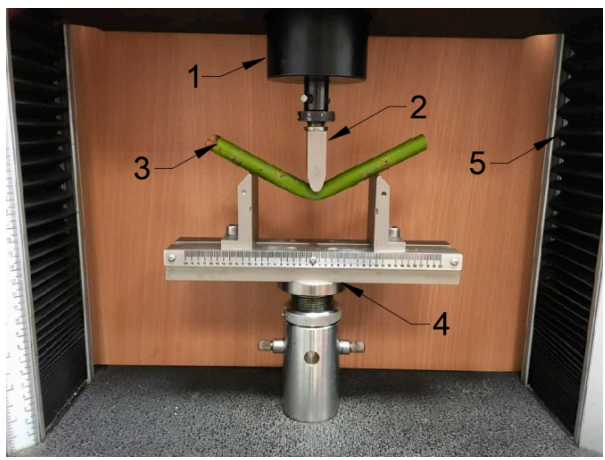

(a)
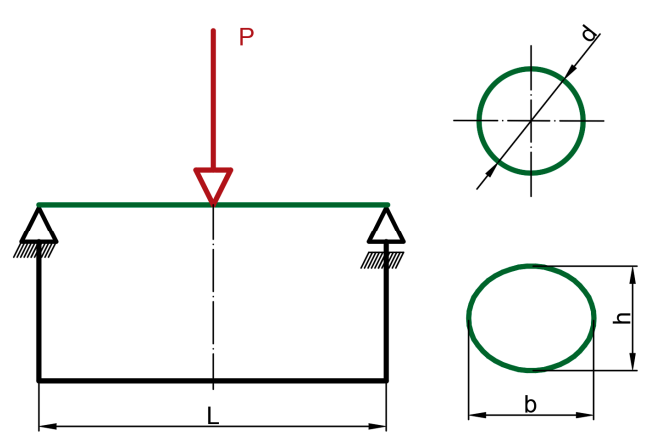

(b)

Figure 4. The measurement station for bending test: (a) View of the measuring instrument: 1-measuring head, 2-measuring adapter, 3-sample, 4-support, 5-guide, (b) Characteristic dimensions: $\mathrm{L}$-length of the sample, $\mathrm{d}$ - diameter, $\mathrm{h}$ - height, $\mathrm{b}$ - width. 
The load was controlled using different displacement speeds $\left(1.8,30,100\right.$ and $\left.500 \mathrm{~mm} \cdot \mathrm{min}^{-1}\right)$ in five repetitions. Based on the analysis of the peak value of the bending force in the displacement function, the modulus of elasticity and breaking stress for stalks were determined using Formulas (4)-(8), accordingly:

$$
\mathrm{Mg}=\frac{\mathrm{P} \cdot \mathrm{L}}{4}
$$

where: $\mathrm{Mg}$ —bending moment $(\mathrm{N} \cdot \mathrm{m}), \mathrm{P}$-force $(\mathrm{N}), \mathrm{L}$-spacing of supports $(\mathrm{mm})$.

$$
\mathrm{Ix}=\frac{\pi \cdot \mathrm{d}^{4}}{64}
$$

where: $\mathrm{Ix}$-the moment of inertia $\left(\mathrm{mm}^{4}\right), \mathrm{d}$-diameter of the stalk $(\mathrm{mm})$.

$$
\mathrm{f}=\frac{\mathrm{P} \cdot \mathrm{L}^{3}}{48 \cdot \mathrm{E} \cdot \mathrm{Ix}}
$$

where: $\mathrm{f}-$ displacement (m), E-Young's modulus (GPa).

$$
\mathrm{Wx}=\frac{\pi \cdot \mathrm{d}^{3}}{32}
$$

where: $\mathrm{Wx}$-bending strength index $\left(\mathrm{mm}^{3}\right)$.

$$
\sigma g=\frac{M g}{W x}
$$

where: $\sigma g$-bending stress $(\mathrm{MPa})$.

\subsection{Procedure of the Impact Strength Test}

The impact strength test was performed using the Charpy method. The measurement method was based on the PN-EN ISO 148-1: 2017-02 standard [24]. Due to the heterogeneity of investigated material and its unique dimensions, the biomass sample was adopted to the applied standard (Figure 5), accordingly. The tests were carried out in five replications.

Potential energy absorption by biomass stalks was obtained from the Charpy impact test. The sample dimensions were determined using a caliper to calculate the fracture area. The following formula was used to determine the impact strength of the samples:

$$
\mathrm{K}=\frac{\mathrm{K}_{1}}{\mathrm{~A}}
$$

where $\mathrm{K}$ is impact strength $\left(\mathrm{J} \cdot \mathrm{cm}^{-2}\right), \mathrm{K}_{1}$ is energy absorbed by the sample $(\mathrm{J})$ and $\mathrm{A}$ is fracture surface $\left(\mathrm{cm}^{2}\right)$. 


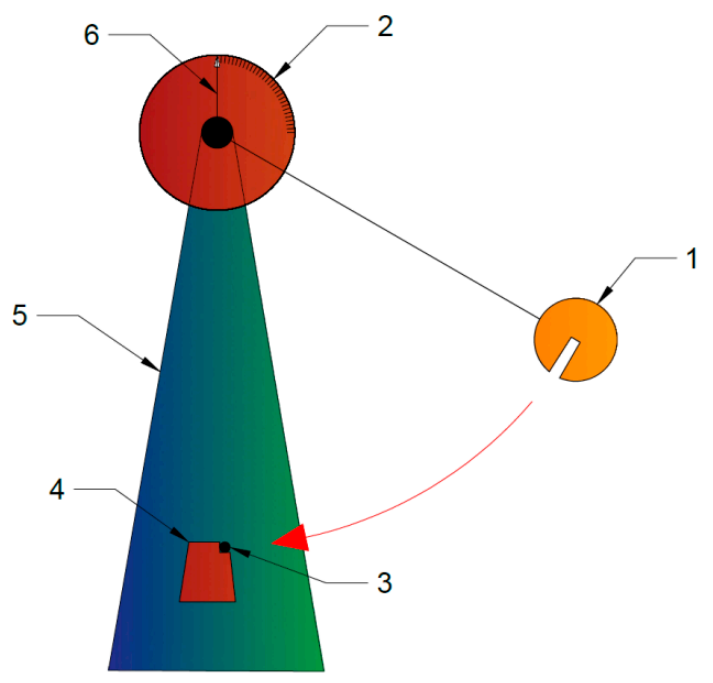

(a) scheme of the measuring instrument

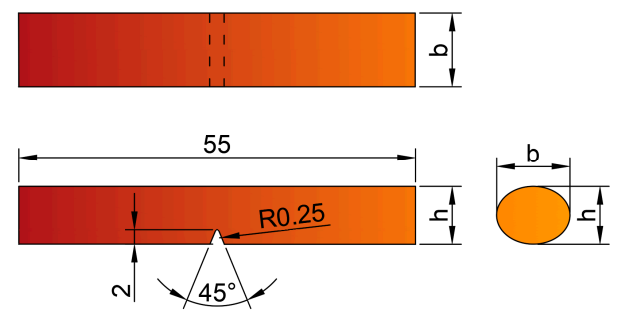

(b) dimensions of the sample

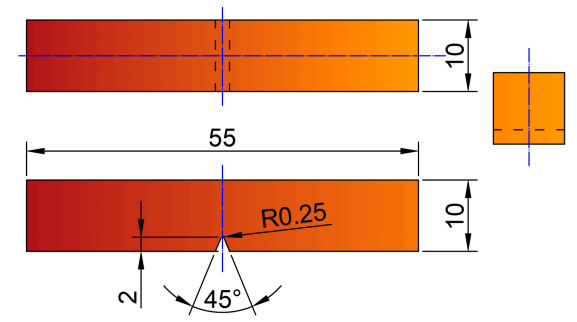

(c) dimensions of the standardized sample

Figure 5. Scheme of the test stand and biomass sample: 1-pendulum, 2-measuring scale, 3-biomass sample, 4-supports, 5-corps, 6-measuring tip, b-width, h-height.

\section{Results and Discussion}

\subsection{Biomass Characteristics}

The results of proximate analysis (moisture and ash content, low heating value, and volatile matter) of investigated energy crops are presented in Table 2.

Table 2. Biomass characteristics.

\begin{tabular}{cccccc}
\hline Material & Moisture Content, $\%$ & Ash, $\%$ & HHV, MJ·kg & LHV, $\mathbf{~ M J \cdot k g - 1 ~}$ & VM, \% \\
\hline Miscanthus $\times$ giganteus & $6.62 \pm 1.37$ & $1.3 \pm 0.9$ & 17.68 & $16.80 \pm 0.83$ & $77.15 \pm 0.14$ \\
Rosa multiflora & $7.77 \pm 0.85$ & $1.9 \pm 1.06$ & 17.54 & $15.88 \pm 0.29$ & $73.37 \pm 0.44$ \\
Salix viminalis & $8.72 \pm 1.19$ & $1.6 \pm 0.92$ & 17.50 & $15.85 \pm 0.39$ & $75.51 \pm 0.85$ \\
\hline
\end{tabular}

The obtained values are very similar to the parameters found in the literature. Vassilev et al. [44] examined the ash content and volatile matter in Miscanthus $\times$ giganteus with a slightly higher result of ash content (4.80\%) and VM of (79.00\%). Lewandowski et al. [45] investigated the values of ash content 
in different seasons in five locations in Europe. Miscanthus $\times$ giganteus cultivated in Portugal, harvested in winter, had the most similar results in terms of ash content. Tursunov et al. [46] determined the same properties of Rosa multiflora ( $2.4 \%$ of ash content and $76.4 \%$ of VM). He also examined the LHV for Miscanthus $\times$ giganteus (16.9 MJ $\cdot \mathrm{kg}^{-1}$ at the moisture content of $8.8 \%$ ) and Rosa multiflora (17.6 MJ $\cdot \mathrm{kg}^{-1}$ at moisture content $18.3 \%$ ). In turn, Weger et al. [47] analyzed Salix viminalis, obtaining the following values: ash content $(1.35 \%)$, VM $(81.02 \%)$ and LHV $\left(18.66 \mathrm{MJ} \cdot \mathrm{kg}^{-1}\right)$.

The strength properties of energy crops were measured for moisture content and the results are presented in Table 3, along with the division into plant zones. The moisture values are typical for investigated energy crops during harvesting process [10,11].

Table 3. The average moisture content in individual zones of energy crops.

\begin{tabular}{cccc}
\hline Moisture Content, $\%$ & Miscanthus $\times$ Giganteus & Rosa Multiflora & Salix Viminalis \\
\hline basal zone (1) & $25.16 \pm 3.91$ & $40.41 \pm 1.35$ & $40.90 \pm 2.83$ \\
middle zone (2) & $16.05 \pm 3.25$ & $43.80 \pm 0.92$ & $43.00 \pm 1.95$ \\
apical zone (3) & $14.33 \pm 2.86$ & $47.02 \pm 1.27$ & $41.98 \pm 2.67$ \\
\hline
\end{tabular}

\subsection{Cutting Resistance of the Biomass}

Tables 4 and 5 show the cutting resistances, strength, and power required for the shredding process at initial rotation speeds of 4200, 3200, 2200 RPM. Unfortunately, the tests revealed that 2200 RPM for the $2.5 \mathrm{~kW}$ power of the engine was too low to crush the material; therefore, the results are shown for an initial speed of 3200 and 4200 RPM only.

Table 4. The average cutting resistance at the initial rotation speed $n_{1}=4200 R P M$.

\begin{tabular}{|c|c|c|c|c|c|c|}
\hline & Surface & Rotation Speed & Torque & Power & Force & Cutting Resistance \\
\hline \multirow{4}{*}{ Miscanthus $\times$ giganteus } & $\mathrm{mm}^{2}$ & RPM & $\mathrm{N} \cdot \mathrm{m}$ & W & $\mathrm{N}$ & $\mathrm{N} \cdot \mathrm{mm}^{-2}$ \\
\hline & 104.58 & 3833 & 1.50 & 603.62 & 22.79 & 0.22 \\
\hline & 267.10 & 3150 & 2.45 & 805.30 & 37.09 & 0.14 \\
\hline & 318.55 & 2833 & 3.39 & 1002.27 & 51.39 & 0.16 \\
\hline \multirow{4}{*}{ Rosa multiflora } & 200.09 & 3200 & 2.05 & 682.93 & 31.03 & 0.16 \\
\hline & 324.54 & 2166 & 3.50 & 798.85 & 53.03 & 0.16 \\
\hline & 368.92 & 2720 & 3.00 & 851.72 & 45.43 & 0.12 \\
\hline & 487.54 & 2400 & 3.92 & 984.32 & 59.43 & 0.12 \\
\hline Salix viminalis & 365.30 & 2766 & 4.08 & 1174.03 & 61.81 & 0.17 \\
\hline
\end{tabular}


Table 5. The average cutting resistance at the initial rotation speed $n_{2}=3200$ RPM.

\begin{tabular}{ccccccc}
\hline & Surface & Rotation Speed & Torque & Power & Force & Cutting Resistance \\
\hline & $\mathrm{mm}^{2}$ & $\mathrm{RPM}$ & $\mathrm{N} \cdot \mathrm{m}$ & $\mathrm{W}$ & $\mathrm{N}$ & $\mathrm{N} \cdot \mathrm{mm}^{-2}$ \\
\cline { 2 - 6 } Miscanthus $\times$ giganteus & 124.74 & 2533 & 1.29 & 343.97 & 19.62 & 0.16 \\
& 128.60 & 2583 & 1.32 & 359.08 & 20.06 & 0.16 \\
& 231.96 & 2286 & 2.13 & 507.68 & 32.27 & 0.14 \\
& 241.27 & 2078 & 2.37 & 515.32 & 35.92 & 0.15 \\
Rosa multiflora & 305.68 & 1760 & 2.30 & 419.04 & 34.92 & 0.11 \\
& 177.45 & 2100 & 1.98 & 429.25 & 29.93 & 0.17 \\
& 324.54 & 1220 & 3.71 & 468.35 & 56.17 & 0.17 \\
& 335.42 & 1603 & 3.18 & 529.63 & 48.22 & 0.14 \\
\multirow{3}{*}{ Salix viminalis } & 354.32 & 1401 & 3.39 & 496.87 & 51.34 & 0.14 \\
& 455.47 & 1073 & 4.41 & 488.29 & 66.75 & 0.15 \\
\hline & 161.19 & 2093 & 2.17 & 488.67 & 32.92 & 0.20 \\
& 196.35 & 1623 & 2.65 & 430.88 & 40.10 & 0.20 \\
& 226.86 & 2133 & 2.18 & 448.19 & 32.97 & 0.15 \\
& 280.95 & 1467 & 3.10 & 475.72 & 46.94 & 0.17 \\
\hline
\end{tabular}

Based on the analysis of Tables 4 and 5, it can be concluded that the highest cutting resistance was achieved by Salix viminalis, reaching values between 0.15 and $0.23 \mathrm{~N} \cdot \mathrm{mm}^{-2}$, for which the cutting resistance increased at the moment of lowering the rotation speed (Figure 6). In contrast to Salix viminalis, Miscanthus $\times$ giganteus and Rosa multiflora showed a reverse strength property, whose cutting resistances were $0.11-0.23 \mathrm{~N} \cdot \mathrm{mm}^{-2}$ and $0.12-0.17 \mathrm{~N} \cdot \mathrm{mm}^{-2}$, respectively. In those cases, the cutting resistance to their shredding increased with the rotation speed. It can be explained by the low modulus of Salix viminalis with a relatively large diameter of stalks.

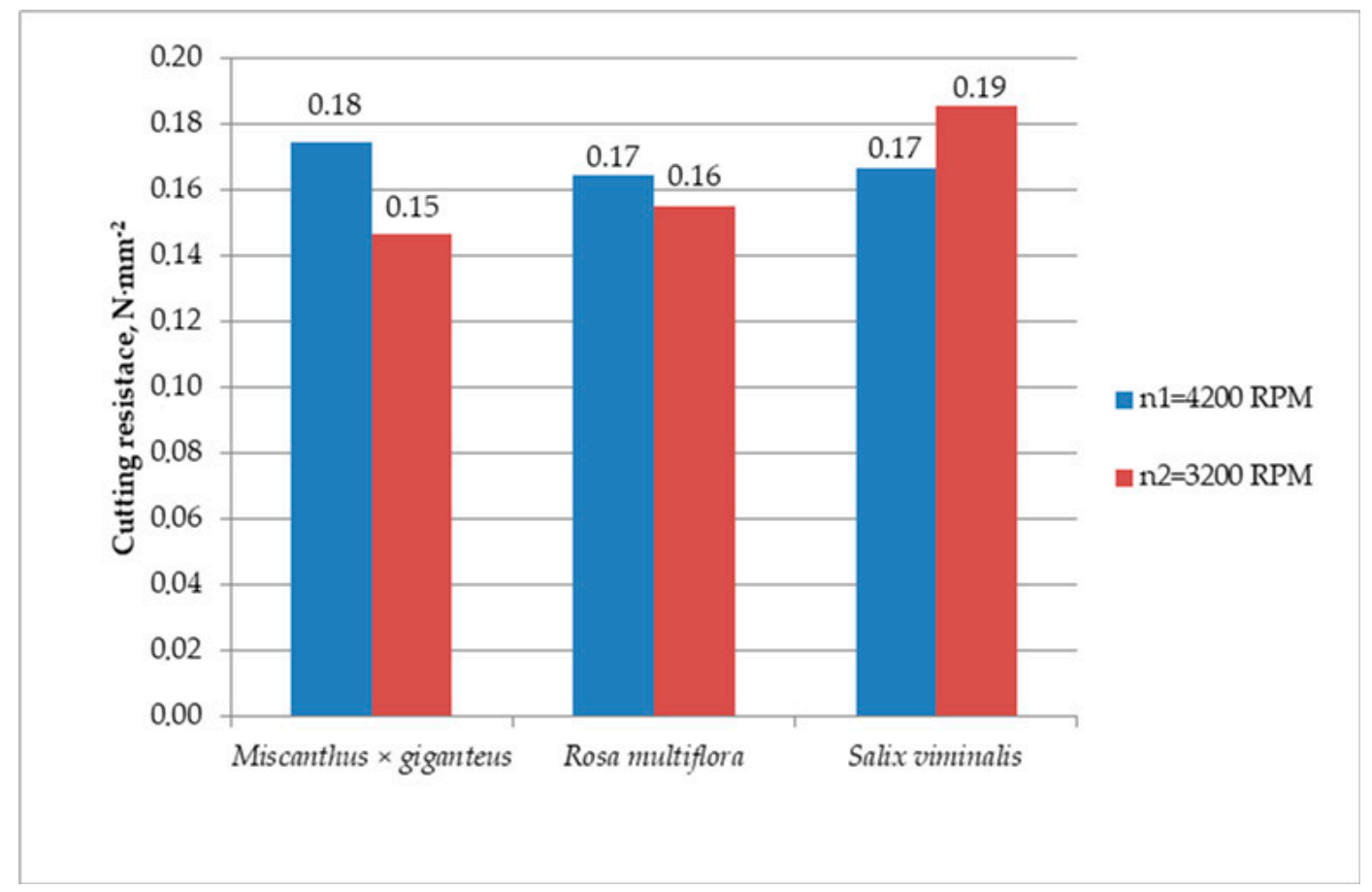

Figure 6. The average cutting resistance at variable rotation speeds.

Chen et al. [30] studied the shear force in quasi-static conditions required for Hemp stalks, which amounted to $243 \mathrm{~N}$. However, this value does not give complete information on the strength of the sample since the cross-section of the sample was not taken into account. 
Chattopadhyay et al. [31] examined the Sorghum stalks for the absorption of a part of the potential energy, thus determining the resistance in the form of energy falling on the shear surface. The results were 0.101-0.142 MJ. $\mathrm{mm}^{-2}$, while Fraczek et al. [29] investigated Topinambur, obtaining results between 0.014 and $0.023 \mathrm{MJ} \cdot \mathrm{mm}^{-2}$. However, both mentioned measurements concerned the energy consumption of the process (taking into account the cross-section of the sample absorbing the energy), and not the cutting resistance, as examined in this work. Therefore, the comparison of the results was not possible.

Lisowski et al. [28] checked the resistance and cutting energy of maize stalks in internodes and nodes, obtaining values of $16.9-60.4 \mathrm{~N} \cdot \mathrm{mm}^{-2}$ and $10.93-26.82 \mathrm{~J} \cdot \mathrm{mm}^{-2}$, depending on the measurement zone. These results showed a significant difference between the cutting resistance in the dynamic and static conditions. The cutting in the quasi-static conditions requires much more energy to cut the stalks compared to the dynamic conditions. Lisowski et al. indicated that the cutting resistance of corn stalks was one hundred times higher than the cutting resistance of Rosa multiflora or Miscanthus $\times$ giganteus at a rotation speed of $3200 \mathrm{RPM}$ obtained in this study $\left(0.15-0.19 \mathrm{~N} \cdot \mathrm{mm}^{-2}\right)$. The cutting energy for rapeseed stalks and pods under dynamic conditions was investigated by Skubisz et al. [25]. The values of the cutting energy were $9.88 \cdot 10^{4} \mathrm{~J} \cdot \mathrm{mm}^{-2}$ for pods and $11.87 \cdot 10^{4} \mathrm{~J} \cdot \mathrm{mm}^{-2}$ for stalks. However, these values cannot be compared with the results of this study, because they take into account the energy only and not the force acting on the shear surface. Similar research was performed for buckwheat stalks by Woliński et al. [26], for which the cutting energy amounted to $0.33-0.39 \mathrm{~J}$. Unfortunately, the authors did not include the shear surface of the investigated material, only the energy needed to cut the stem was considered, so the results of the test cannot be compared, as well.

Yore et al. [32] investigated the cutting energy for rice straw at the cutting speed of 500 strokes per minute. The results showed that as the number of stems (cutting surface) increases, the amount of energy needed to cut one stem decreases. The highest value of shearing energy for one rice straw stem was $0.22 \mathrm{~J}$, while average shearing energy per stem was $0.15 \mathrm{~J}$ (for a five-stem test). The highest peak force was $8.3 \mathrm{~N}$ for one stem and $5 \mathrm{~N}$ per stem for normalized results. Unfortunately, as the energy and the shear force did not correspond to the cutting surface, the values cannot be compared with the results obtained in this study.

In turn, Igathinathane et al. [33] investigated the influence of the position of the corn stalks relative to the cutting blade. The results showed that the highest cutting force required the corn stalks to be oriented perpendicular to the blade $(242 \mathrm{~N})$, while for stalks set at an angle of 45 degrees, the force was $127 \mathrm{~N}$, and for the parallel set only $46 \mathrm{~N}$. In the case of these tests, the cutting cross-section was also not taken into account; moreover, the tests were carried out under quasi-static conditions, which prevented comparison of the results.

Unfortunately, none of the mentioned publications ([25,26,28-33]) contained studies related to the shear force under the dynamic conditions and referred to the cross-section of the sample.

Based on the trend line (linear equation, in this case), it was observed that the increase in rotation speed causes a slight reduction in shearing forces (Figures 7 and 8). Such a slight difference means that the force needed for comminution is similar in both cases; however, a minimal increase in force when lowering the speed indicates that a further increase in force can be expected along with lowering the rotation speed, as it was detected using a speed of 2200, at which cutting resistance was not high enough to make it impossible to crumble the material. At a rotation speed of $4200 \mathrm{RPM}$, the force concerning the shear area increased more linearly. Additionally, the Miscanthus $\times$ giganteus at a rotation speed of 4200 RPM showed a similar relationship of force to the surface like for Rosa multiflora, while at a speed of 3200 RPM, Rosa multiflora showed a higher cutting resistance. 

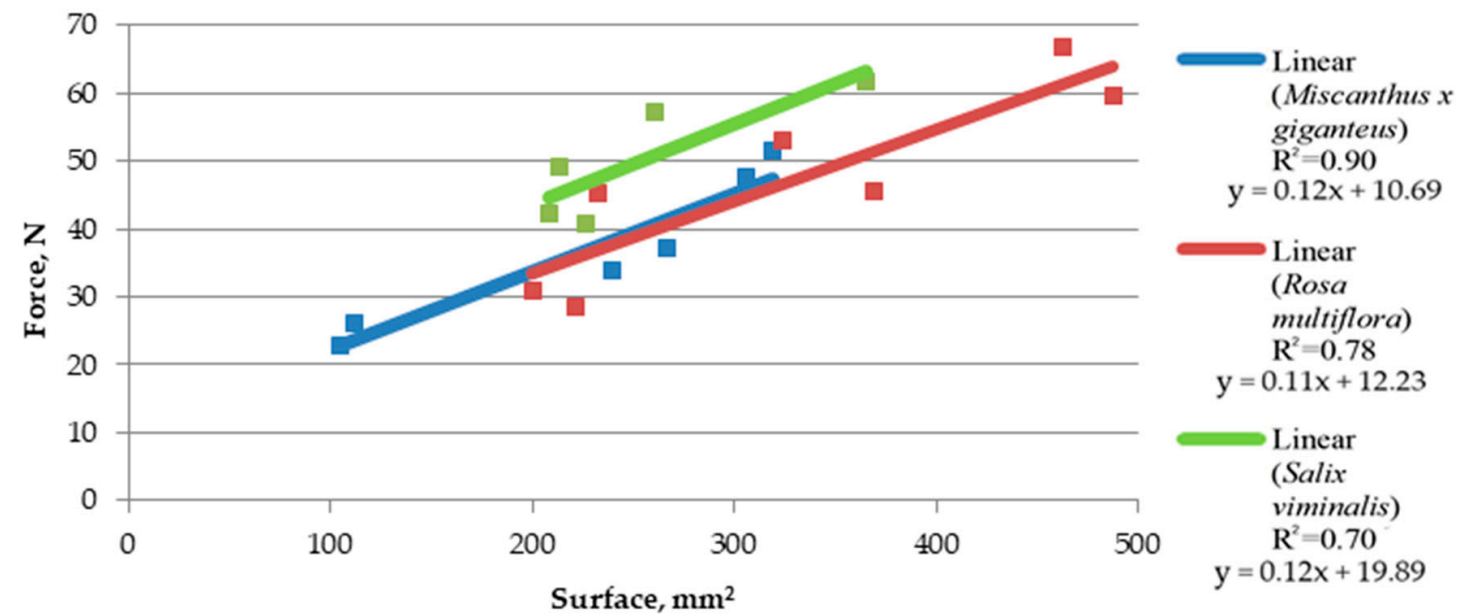

Figure 7. The average cutting force for the initial rotation speed $n_{1}=4200$ RPM.
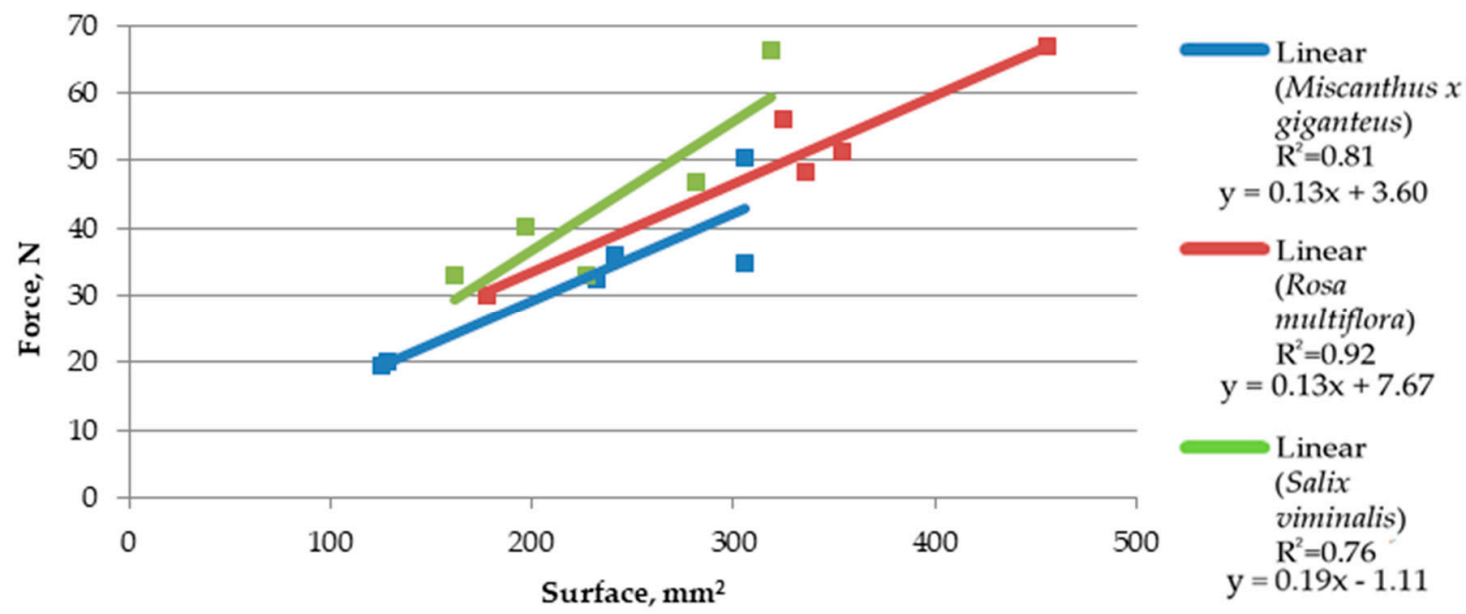

Figure 8. The average cutting force for the initial rotation speed $n_{2}=3200$ RPM.

The increasing torque causes a reduction of the rotation speed under the load, which increases the shear force. The highest decrease in rotation speed was observed for Salix viminalis, characterized by the highest value of the shear resistance, while the lowest decrease was observed for Miscanthus $\times$ giganteus, characterized by the lowest shear resistance (Figures 9-11).

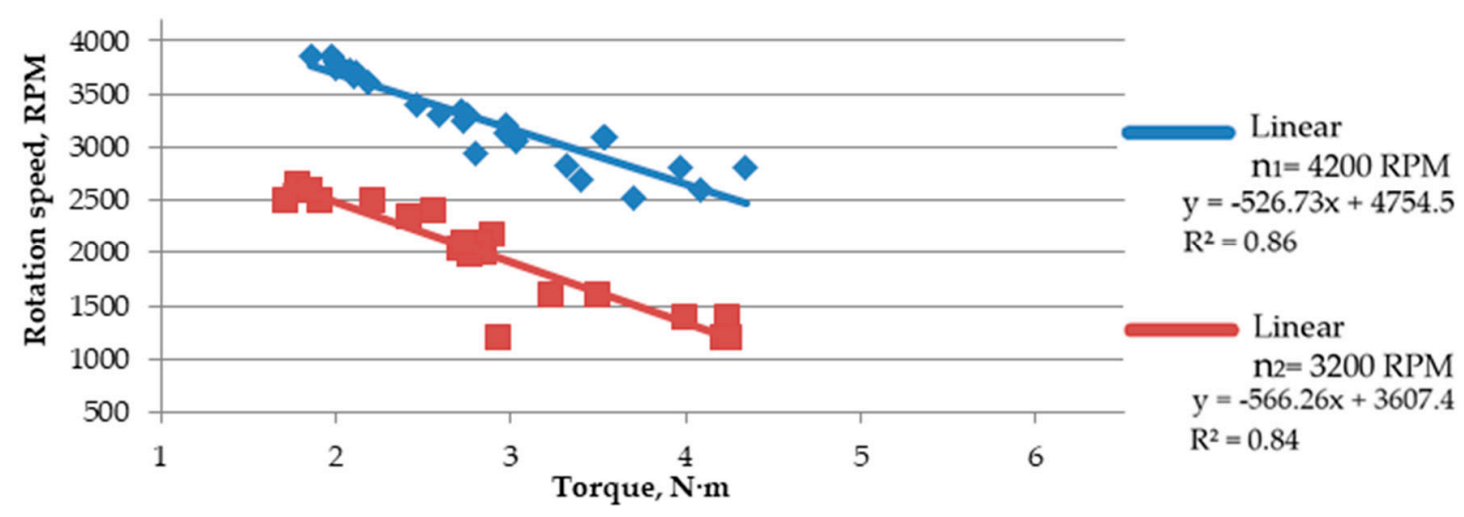

Figure 9. The dependence of rotation speed to torque for Miscanthus $\times$ giganteus. 


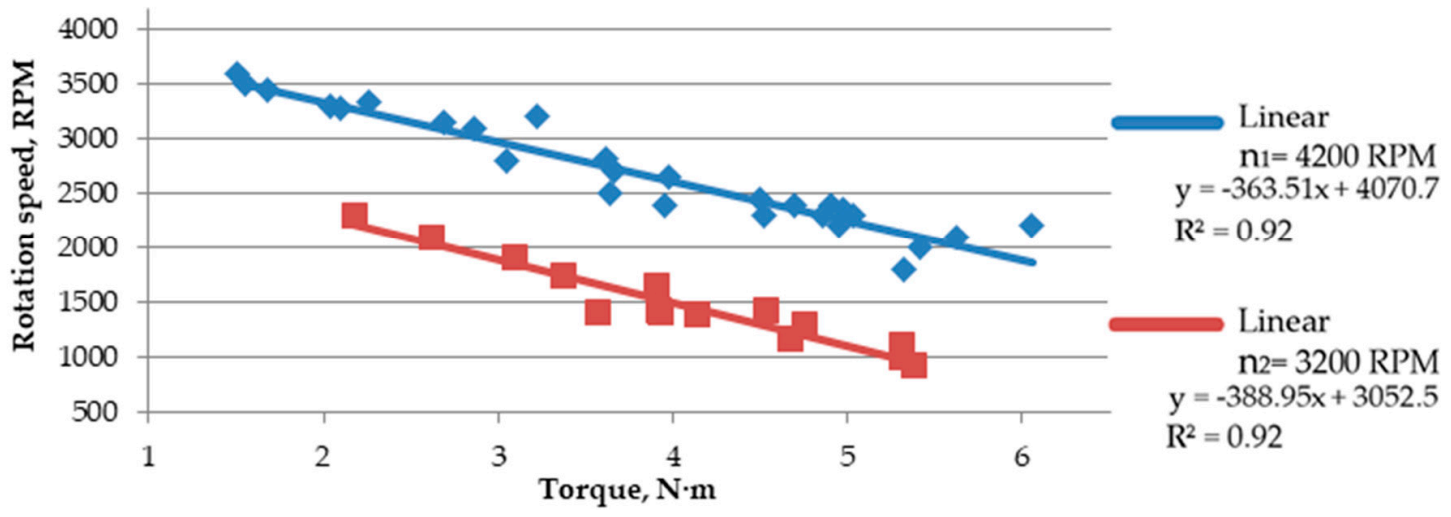

Figure 10. The dependence of the rotation speed vs. torque for Rosa multiflora.

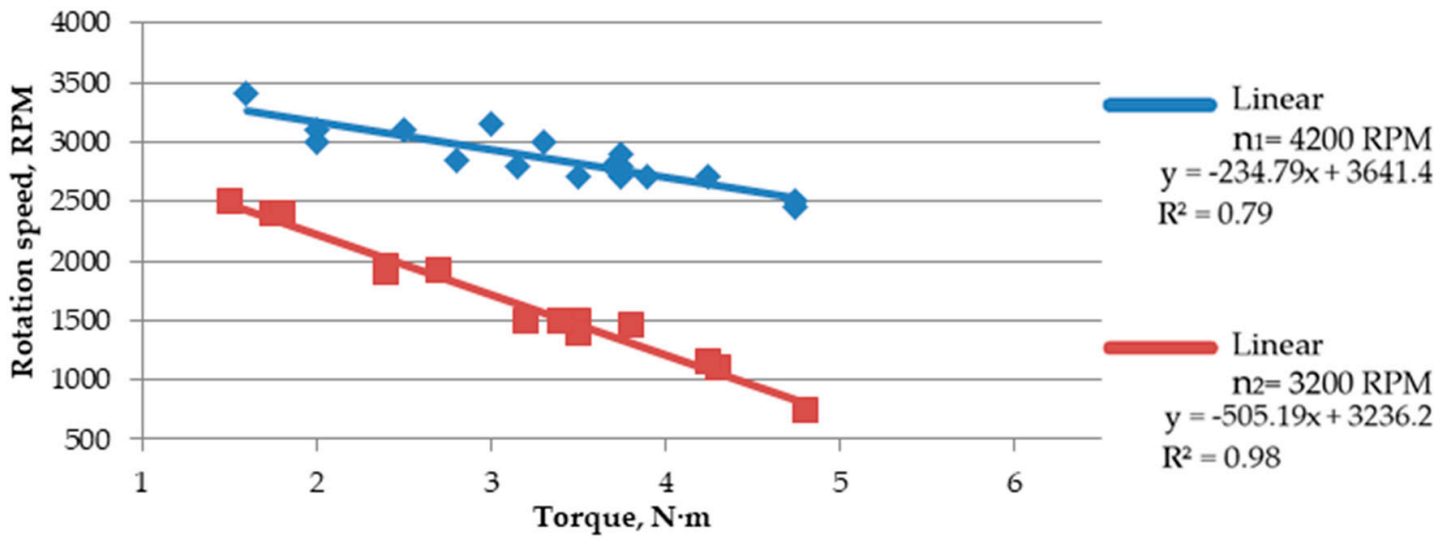

Figure 11. The dependence of the rotation speed vs. torque for Salix viminalis.

Additionally, the application of the statistical method ANOVA (Analysis of Variance) revealed that the surface (cross-section area) had the greatest influence on the cutting force for Miscanthus $\times$ giganteus and Rosa multiflora. In the case of Salix viminalis, a weak dependence of strength on the other parameters was observed. The details of this analysis (at the probability value $p<0.05$ ) are presented in the Supplementary Materials (Table S1). In turn, for Miscanthus $\times$ giganteus, the analysis showed a dependence of cutting resistance on all invetigated parameters (Table S2 in Supplementary Materials).

Analysis of force variance and cutting resistance depending on the initial speed and decrease in rotation, presented in Supplementary Materials (Tables S3 and S4) showed the relationship between force and rotation speeds for Miscanthus $\times$ giganteus and Salix viminalis. However, the relationship between cutting resistance and rotation speeds was observed only for Miscanthus $\times$ giganteus. There was no correlation between the considered parameters for Salix viminalis.

The studies showed also that for a greater rotation speed (4200 RPM in this case) the power demand for the investigated energy plants chipping increased in relation to the lower rotation speed (3200 RPM in this case). The power demand can be calculated using the following formula:

$$
\mathrm{P}=\frac{2 \cdot \pi \cdot \mathrm{n} \cdot \mathrm{M}}{60}
$$

where: $\mathrm{P}$ is a power $(\mathrm{W}), \mathrm{n}$ is a rotation speed $(\mathrm{RPM})$, and $\mathrm{M}$ is a torque $(\mathrm{N} \cdot \mathrm{m})$.

For a rotation speed of $4200 \mathrm{RPM}$, the power needed to chop the material was $802 \mathrm{~W}$ for Miscanthus $\times$ giganteus, $806 \mathrm{~W}$ for Rosa multiflora and $896 \mathrm{~W}$ for Salix viminalis, while at $3200 \mathrm{RPM}$ the power demand for Miscanthus $\times$ giganteus was $438 \mathrm{~W}$ for Rosa multiflora $482 \mathrm{~W}$ and $467 \mathrm{~W}$ for Salix viminalis. The differences between the power demanded for branch chipping at the given rotation speeds (3200 RPM and 4200 RPM) differed by $48 \%$ for Salix viminalis, $45 \%$ for Miscanthus $\times$ giganteus and $40 \%$ for Rosa multiflora, respectively. Thus, the rotation speed indirectly influences energy consumption 
during biomass processing (cutting, chipping, shredding). As a result, the rotation speed significantly affects also the energy efficiency of those processes, and its selection is an indispensable parameter that should not be overlooked during the selection of the equipment and settings of the operation conditions. During the test, it was observed that for Miscanthus $\times$ giganteus and Rosa multiflora, the cutting resistance was increasing along with rotation speed, in contrast to Salix viminalis. This relationship is due to Salix viminalis requiring higher blade rotation speeds because it is resistant to impact forces and its comminution is only due to the cutting forces. It is important information from a biomass processing point of view, indicating that the cutting efficiency, the energy consumption and the equipment used at a given rotation speed may not be effective for every type of energy plant.

\subsection{Impact Strength Test of the Biomass}

Based on the results of the tests carried out, it was found that the highest impact strength value was observed for Salix viminalis. The energy needed to break it went beyond the range of the measuring instrument and amounted to above $0.57 \mathrm{~J} \cdot \mathrm{mm}^{-2}$. Tables 6 and 7 show the results of the Charpy impact test for Miscanthus $\times$ giganteus and Rosa multiflora. Based on the results, it can be concluded that Rosa multiflora has a higher impact strength than Miscanthus $\times$ giganteus. For Rosa multiflora, the energy absorbed exceeded twice the measuring range of the stand.

Table 6. Impact strength of Miscanthus $\times$ giganteus.

\begin{tabular}{cccccc}
\hline Width $\mathbf{( b )}$ & High $(\mathbf{h})$ & Surface $(\mathbf{A})$ & Potential Energy $\left.\mathbf{( K}_{\mathbf{p}}\right)$ & Absorbed Energy $\left(\mathbf{K}_{\mathbf{1}}\right)$ & Impact Strength $(\mathbf{K})$ \\
\hline $\mathrm{mm}$ & $\mathrm{mm}$ & $\mathrm{mm}^{2}$ & $\mathrm{~J}$ & $\mathrm{~J}$ & $\mathrm{~J} \cdot \mathrm{mm}^{-2}$ \\
8.33 & 6.76 & 44.22 & & 7.50 & 0.17 \\
9.11 & 7.25 & 51.87 & & 7.00 & 0.13 \\
12.55 & 10.63 & 104.78 & 40.00 & 27.00 & 0.26 \\
11.59 & 9.05 & 82.38 & & 20.00 & 0.24 \\
8.41 & 6.78 & 44.78 & & 8.00 & 0.18 \\
11.81 & 9.56 & 88.67 & & 27.00 & 0.30 \\
\hline
\end{tabular}

The differences in measurements were significant, and resulted from both the surface of the sample cross-section and the sampling zone, for the Miscanthus $\times$ giganteus standard deviation was $0.15 \mathrm{~J} \cdot \mathrm{mm}^{-2}$ and for the Rosa multiflora $0.06 \mathrm{~J} \cdot \mathrm{mm}^{-2}$. The highest value of Rosa multiflora impact strength was $0.77 \mathrm{~J} \cdot \mathrm{mm}^{-2}$, with an average impact strength $0.53 \mathrm{~J} \cdot \mathrm{mm}^{-2}$, while the lowest value was $0.32 \mathrm{~J} \cdot \mathrm{mm}^{-2}$. For Miscanthus $\times$ giganteus, the highest value amounted $0.30 \mathrm{~J} \cdot \mathrm{mm}^{-2}$ and the lowest one was $0.13 \mathrm{~J} \cdot \mathrm{mm}^{-2}$. Moreover, applying ANOVA, a high dependence of impact strength (at the $p<0.05$ ) on the surface was found for Miscanthus $\times$ giganteus, as shown in the Supplementary Materials (Table S5).

Table 7. Impact strength of Rosa multiflora.

\begin{tabular}{cccccc}
\hline Width (b) & High (h) & Surface (A) & Potential Energy $\left.\mathbf{( K}_{\mathbf{p}}\right)$ & Absorbed Energy $\left(\mathbf{K}_{\mathbf{1}}\right)$ & Impact Strength (K) \\
\hline $\mathrm{mm}$ & $\mathrm{mm}$ & $\mathrm{mm}^{2}$ & $\mathrm{~J}$ & $\mathrm{~J}$ & $\mathrm{~J} \cdot \mathrm{mm}^{-2}$ \\
\hline 8.70 & 8.47 & 57.87 & & 18.50 & 0.32 \\
9.58 & 8.74 & 65.76 & & 33.00 & 0.50 \\
9.60 & 9.27 & 69.76 & 40.00 & 40.00 & $0.57<$ \\
10.13 & 9.62 & 76.53 & & 40.00 & $0.52<$ \\
8.75 & 8.71 & 59.86 & & 30.00 & 0.50 \\
7.65 & 7.60 & 45.66 & 35.50 & 0.77 \\
\hline
\end{tabular}

The impact tests carried out led to the conclusion that Miscanthus $\times$ giganteus belongs to the group of plants characterized by a low impact strength, which indicates its fragility. Therefore, it is more suitable for impact crushing than cutting. The difference in impact strength in the tested plants proves that the grinding methods should be properly selected, depending on their mechanical properties. Grinding a plant with a low impact strength (Miscanthus $\times$ giganteus) using knives may be unnecessary 
and economically unprofitable, as its apparent cutting may result from its crushing. Then, it is unnecessary to use and constantly replace expensive blades, because a better solution would be to use a hammer mill.

\subsection{Bending Stiffness of the Biomass}

The dependence of Young's modulus, bending stress and bending stiffness on the stalk measurement zone are shown in Figures 12-14. In the case of Young's modulus (Figure 12), significantly higher values were observed for Miscanthus $\times$ giganteus. The greatest value was obtained in the middle zone of the stalk (4.42 GPa). In the basal and apical zones, Young's modulus amounted to $2.93 \mathrm{GPa}$ and $2.97 \mathrm{GPa}$, respectively. The maximum achieved in the middle zone can be explained by the fact that Miscanthus $\times$ giganteus stalk is thick, but hollow in the basal zone, which weakens it in terms of the strength of the material against bending. The middle zone is filled with tissue in the whole volume and relatively thicker and stronger than the apical zone. In the case of Salix viminalis and Rosa multiflora, Young's modulus was much lower. Depending on the zone, for Salix viminalis, it was 0.13-0.29 GPa, and for Rosa multiflora, it was 0.15-0.22 GPa. This arises from the fact, that both plants have morphological features completely different from Miscanthus $\times$ giganteus. Salix viminalis and Rosa multiflora are flexible and contain much more reinforcing tissue cells responsible for their elasticity.

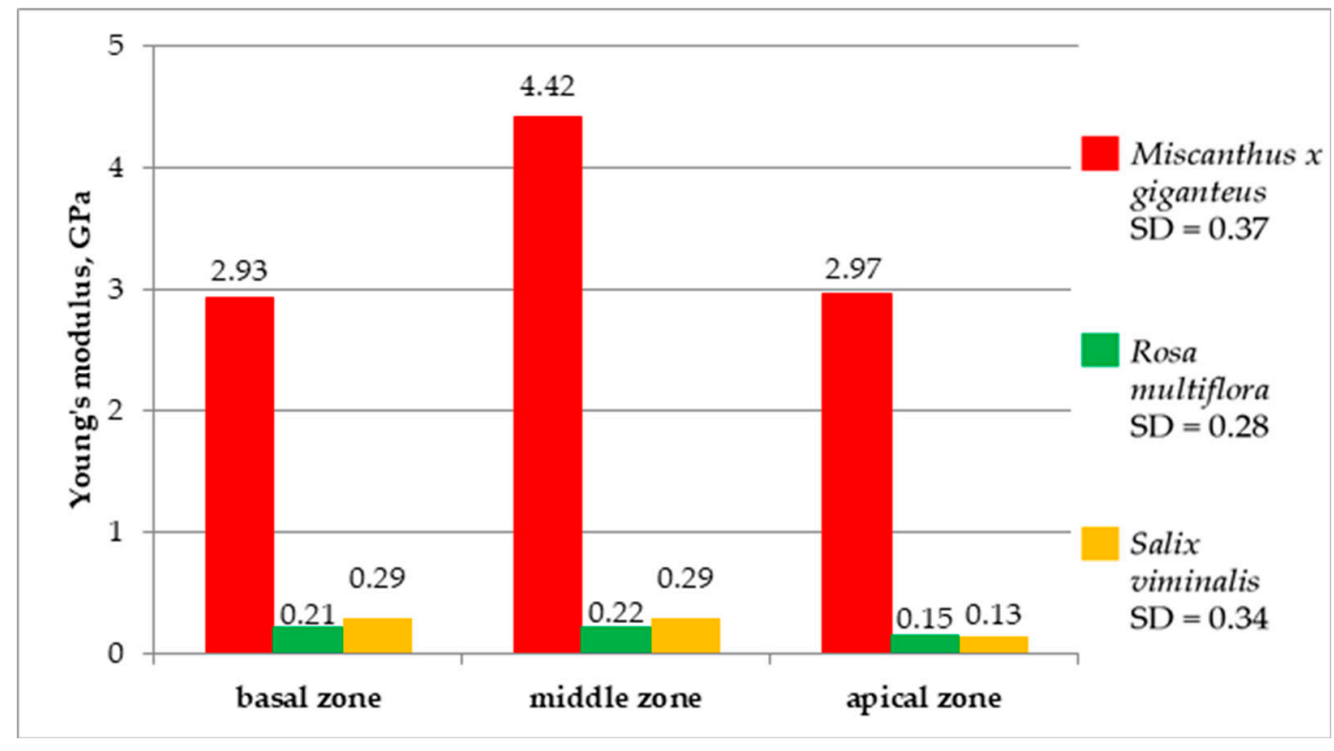

Figure 12. The average Young's modulus of the investigated biomass.

These results are in line with the values obtained by Nowakowski et al. [35]. The Young's modulus determined by the authors were as follows: for Salix viminalis, $0.29-0.58 \mathrm{GPa}$; Rosa multiflora, 0.85-1.67 GPa, Miscanthus $\times$ giganteus, 1.70-1.84 GPa. The deviations in the measurement results are probably caused by the differences in the maturity of the plants, the time of harvesting, and the moisture content of the material. Kaack et al. [48] also performed the tests of Young's modulus for Miscanthus $\times$ giganteus, reaching similar values in the range of 2-8 GPa.

The results of bending stress for the investigated energy plants are shown in Figure 13. The highest values of bending stresses reached Rosa multiflora 38.75-58.95 MPa. Miscanthus $\times$ giganteus oscillated within 30.05-50.49 MPa, while the values for Salix viminalis were in the range 26.58-35.18 MPa. 


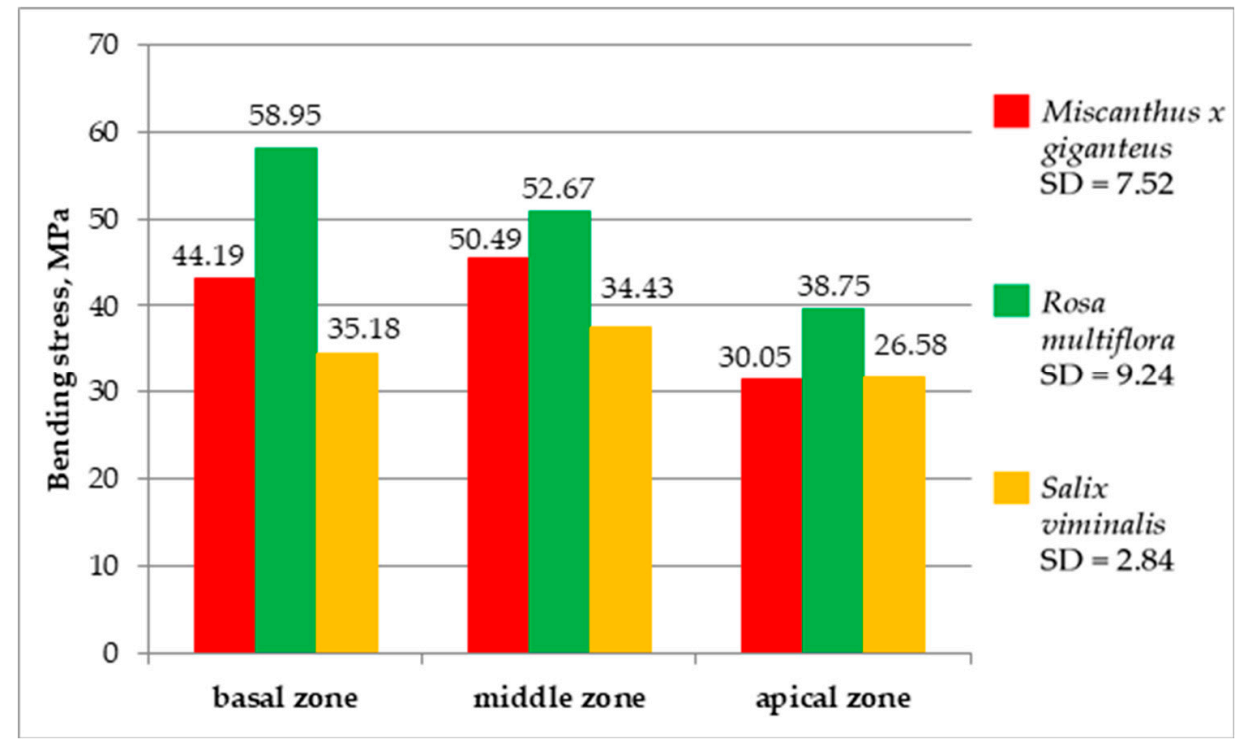

Figure 13. The average bending stress of the investigated biomass.

Differences were found in bending stresses between the zones. Rosa multiflora and Salix viminalis achieved the highest values of bending stress in the basal zone and the lowest in the apical zone. Meanwhile, Miscanthus $\times$ giganteus achieved the highest value of bending stresses in the central zone. The reason for this was that the central zone was characterized by the highest strength properties, because it was lignified enough to have a high concentration of reinforcing tissue, while it was not ripe enough to develop a hole in the stalk, weakening the stalk to forces acting along its cross-section.

Finally, the bending stiffness in three zones of the energy plants was investigated (Figure 14). The highest bending stiffness was achieved by Miscanthus $\times$ giganteus. The values amounted as follow: $1.1 \mathrm{~N} \cdot \mathrm{m}^{2}$ for the basal zone, $0.78 \mathrm{~N} \cdot \mathrm{m}^{2}$ in the central zone and $0.72 \mathrm{~N} \cdot \mathrm{m}^{2}$ for the apical zone.

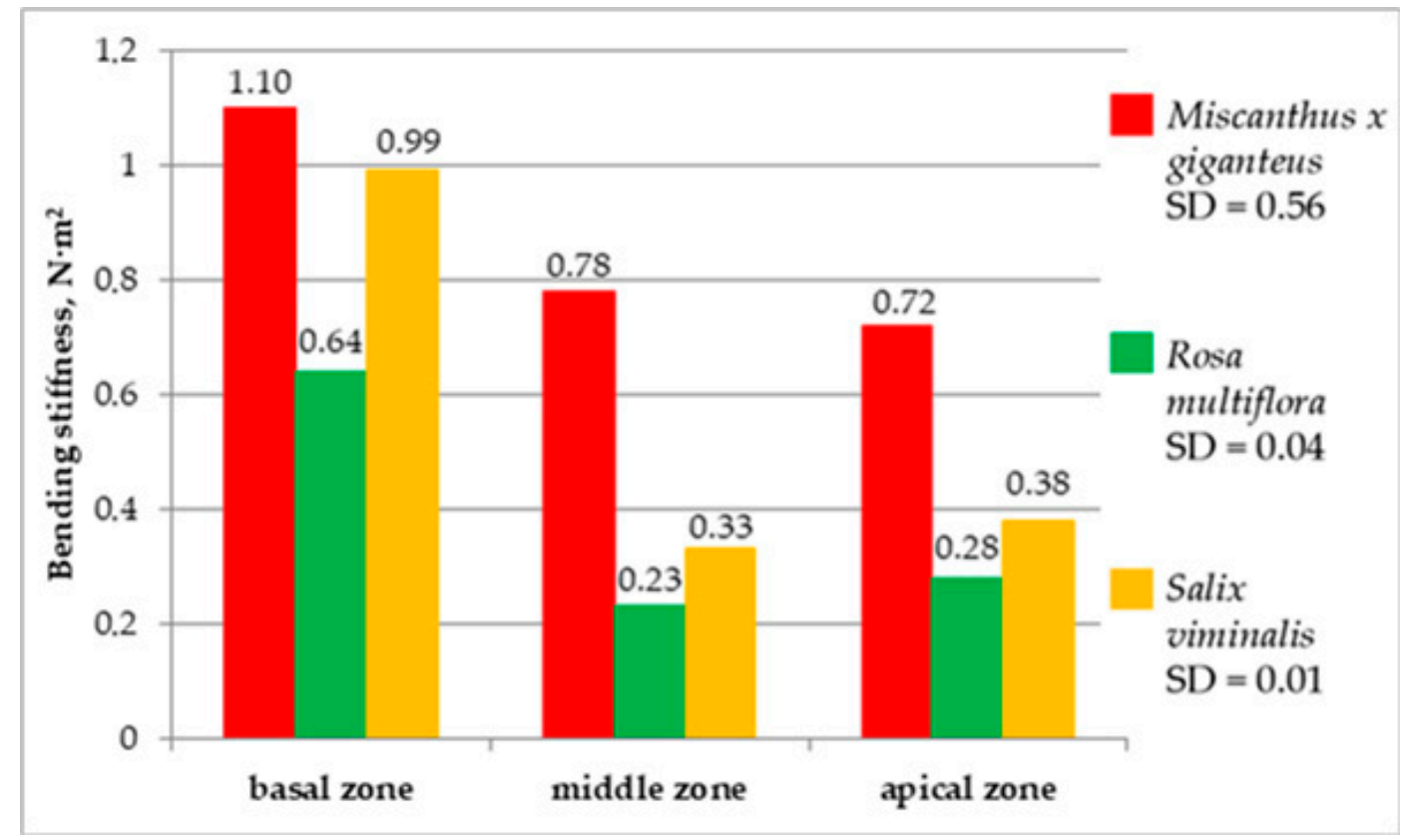

Figure 14. The average bending stiffness of the investigated biomass.

The lowest value of bending stiffness was recorded for Rosa multiflora, for which the highest result was achieved by the basal zone $\left(0.64 \mathrm{~N} \cdot \mathrm{m}^{2}\right)$ and the lowest by middle zone $0.23 \mathrm{~N} \cdot \mathrm{m}^{2}$, in the apical zone 
the value of the stiffness was $0.28 \mathrm{~N} \cdot \mathrm{m}^{2}$. Salix viminalis achieved the following results: for the basal zone, $0.99 \mathrm{~N} \cdot \mathrm{m}^{2}$; middle zone, $0.33 \mathrm{~N} \cdot \mathrm{m}^{2}$; and apical zone $0.38 \mathrm{~N} \cdot \mathrm{m}^{2}$. The basal zone was characterized by the greatest stiffness for all investigated energy plants. As the plant grows, the thickness of the stalk increases, reducing its flexibility, as well as its susceptibility during the baling process. On the other hand, too low a stiffness of the plant may have a negative impact on the cutting process; however, tests of cutting resistance have determined that at given stiffness the middle and apical zone of plants are susceptible to crushing by the knife method.

During the cutting resistance tests, the Miscanthus $\times$ giganteus was shredded due to the impact strength of the blade than because of the cutting force. Such a behavior of the investigated biomass is confirmed by the results of the bending stiffness, stress and Young's modulus tests. Miscanthus $\times$ giganteus was the most fragile plant characterized by the highest bending stiffness and much higher Young's modulus in relation to Rosa multiflora and Salix viminalis.

Additionally, the initial correlation between physical parameters was studied. Based on graphical maps in Figure 15, it can be concluded that the bending stiffness increased with the sample diameter. The speed of sample loading did not significantly affect the results of bending stiffness and bending stress. The apical zone was characterized by smaller stresses during sample loading, which was related to the bending rigidity decreasing along with the diameter.

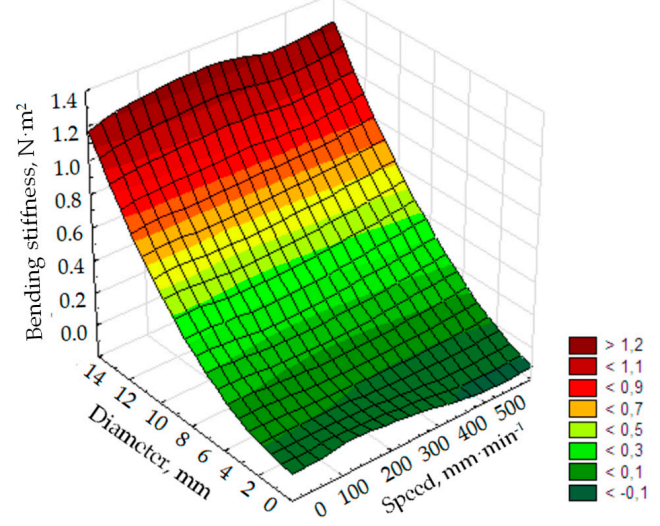

(a) Relationship between stiffness, diameter, and load speed

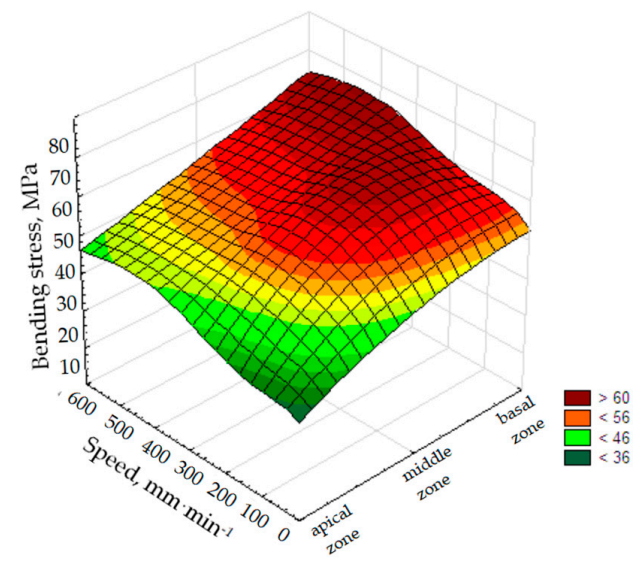

(b) Relationship between bending stress, load speed, and measured zone

Figure 15. Characteristic features of energy crop strength properties.

The analysis of variance was also performed in the case of the tests of the bending stiffness (Tables S6 and S7 in the Supplementary Materials). The aim was to determine the influence of the stalks' diameter, measuring zone and speed of sample loading on the bending stiffness of the investigated energy plants (stalks). According to the results shown in Table S7, a significant dependence of bending stiffness on the diameter was observed for Rosa multiflora and Salix viminalis. For Miscanthus $\times$ giganteus, this correlation was not as relevant. The bending stiffness is also affected by speed and measuring zone (Table S7), but these parameters do not have an influence as great as that of the diameter of the plant (Table S6). The results seem to be satisfactory, but they need further verification, including tests with the use of other plants.

\section{Conclusions}

Knowledge regarding biomass mechanical properties is very important, as its potential utilization for energy purposes is still growing, especially in terms of energy crops and waste raw materials. The strength parameters influence machinery selection and other materials used during biomass processing (especially harvesting and shredding). The understanding of the biomass behavior 
contributes to the reduction of energy consumption, operation time and limitation of unexpected failures, and thus renewable fuel production costs.

The studies showed that energy plants have different mechanical properties. As a result, to optimize the process of further processing, it is necessary to use other technologies or machines. The mechanical tests with the use of Miscanthus $\times$ giganteus, Salix viminalis, and Rosa multiflora provided data supporting the decision making in proper planning of the harvested biomass treatment.

In terms of the processes' efficiency, it seems to be necessary to continue further measurements of the cutting efficiency at given rotation speeds using sieve analysis and to test the energy consumption by machinery using both methods of impact: grinding and cutting. Moreover, the expanding data regarding the strength properties of plants and the impact of various loads can be obtained using the finite element method on the designed discrete model of the plant. More studies are also required to validate the correlation model concerning the mechanical fuel properties, operation conditions of the cutting machinery and size of the energy plants.

Supplementary Materials: The following are available online at http://www.mdpi.com/1996-1073/12/19/3660/s1, Table S1: Correlation analysis for force dependent variable of surface and rotation speeds. Table S2: Correlation analysis for cutting resistance dependent variable of surface and rotation speeds. Table S3: Analysis of the force dependent variable from rotation speed and rotation decrease. Table S4: Analysis of the cutting resistance dependent variable from initial rotation speed and rotation decrease. Table S5: Multivariate analysis of variance for the impact strength dependent variable from the surface independent variable. Table S6: Correlation between stiffness, diameter and measuring speed for each of the plants concerned. Table S7: Bending stiffness variance analysis for speed and zone.

Author Contributions: M.S. and R.S. conceived, designed and performed the research; M.S. and A.D. analyzed the data, contributed materials analysis tools and wrote the paper.

Funding: This research received no external funding. The APC was funded by the Institute of Agricultural Engineering of the Wroclaw University of Environmental and Life Sciences (Statutory activity B010/0036/19).

Conflicts of Interest: The author declares no conflict of interest.

\section{Abbreviations}

$\begin{array}{ll}\text { AC } & \text { ash content } \\ \text { CAP } & \text { Common Agricultural Policy } \\ \text { EC } & \text { European Commission } \\ \text { EU } & \text { European Union } \\ \text { HHV } & \text { higher heating value } \\ \text { LHV } & \text { lower heating value } \\ \text { MC } & \text { moisture content } \\ \text { VM } & \text { volatile matter content }\end{array}$

\section{References}

1. World Bioenergy Association. WBA Global Bioenergy Statistics 2018; World Bioenergy Association: Stockholm, Sweden, 2018.

2. Eurostat. Energy Consumption in Households. Available online: https://ec.europa.eu/eurostat/statisticsexplained/index.php/Energy_consumption_in_households (accessed on 29 May 2019).

3. European Commission. EUROPE 2020: A Strategy for Smart, Sustainable and Inclusive Growth; European Commission: Brussels, Belgium, 2010.

4. Sher, F.; Pans, M.A.; Sun, C.; Snape, C.; Liu, H. Oxy-fuel combustion study of biomass fuels in a $20 \mathrm{kWth}$ fluidized bed combustor. Fuel 2018, 215, 778-786. [CrossRef]

5. Sher, F.; Pans, M.A.; Afilaka, D.T.; Sun, C.; Liu, H. Experimental investigation of woody and non-woody biomass combustion in a bubbling fluidised bed combustor focusing on gaseous emissions and temperature profiles. Energy 2017, 14, 2069-2080. [CrossRef]

6. Ericsson, K.; Nilsson, J.N. Assessment of the potential biomass supply in Europe using a resource-focused approach. Biomass Bioenergy 2006, 30, 1-15. [CrossRef] 
7. Moya, R.; Tenorio, C.; Oporto, G. Short Rotation Wood Crops in Latin American: A Review on Status and Potential Uses as Biofuel. Energies 2019, 12, 705. [CrossRef]

8. Bioenergy Europe. Bioenergy Europe Statistical Report 2019; Report Biomass Supply; Bioenergy Europe: Brussels, Belgium, 2019.

9. Bioenergy Europe. Bioenergy Explained 5. Biomass for Energy: Agricultural Residues E Energy Crops; Bioenergy Europe: Brussels, Belgium, 2018.

10. Mirkowski, T.; Mokrzycki, E.; Uliasz-Bocheńczyk, A. Energetyczne wykorzystanie biomasy. IGSMiE PAN 2018, 49-118.

11. Majcherczyk, A.; Hüttermann, A.; Kües, U. (Eds.). Wood as Renewable Energy Source. Wood Production, Wood Technology, and Biotechnological Impacts; Universitätsverlag Göttingen: Göttingen, Germany, 2007; Volume 1, pp. 99-104.

12. Szczukowski, S.; Tworkowski, J.; Stolarski, M.; Fortuna, W. Plon biomasy wierzby pozyskanej w krótkich rotacjach zbioru na plantacji przemysłowej. Fragm. Agron. 2009, 26, 146-155.

13. Kieć, J.; Łabza, D.; Wieczorek, D. Róża wielokwiatowa (Rosa multiflora) odmiany jatar na cele energetyczne. Fragm. Agron. 2011, 28, 35-41.

14. Klima, K.; Lepiarczyk, A.; Synowiec, A. Economic aspect of Rosa Multiflora thunb. biomass production. Agric. Eng. 2015, 19, 61-67. [CrossRef]

15. Lewandowski, I.; Clifton-Brown, J.; Trindade, M.L.; van der Linden, G.C.; Schwarz, K.W.; Müller-Sämann, K.; Anisimov, A.; Chen, C.L.; Dolstra, O.; Donnison, I.S.; et al. Progress on Optimizing Miscanthus Biomass Production for the European Bioeconomy: Results of the EU FP7 Project OPTIMISC. Front. Plant Sci. 2016, 7, 1620. [CrossRef]

16. Lisowski, A.; Klonowski, J.; Sypuła, M.; Chlebowski, J.; Kostyra, K.; Nowakowski, T.; Strużyk, A.; Świętochowski, A.; Dąbrowska, M.; Mieszkalski, L.; et al. Energy of feeding and chopping of biomass processing in the working units of forage harvester and energy balance of methane production from selected energy plants species. Biomass Bioenergy 2019, 128, 105301. [CrossRef]

17. O'Dogherty, M.J. A review of research on forage chopping. J. Agric. Eng. Res. 1982, 27, 267. [CrossRef]

18. Niedziółka, I.; Szpryngiel, M. Możliwości wykorzystania biomasy na cele energetyczne. Agric. Eng. 2014, 18, 155-164. [CrossRef]

19. Dyjakon, A. Harvesting and Baling of Pruned Biomass in Apple Orchards for Energy Production. Energies 2018, 11, 1680. [CrossRef]

20. Pari, L.; Alfano, V.; Garcia-Galindo, D.; Suardi, A.; Santangelo, E. Pruning Biomass Potential in Italy Related to Crop Characteristics, Agricultural Practices and Agro-Climatic Conditions. Energies 2018, 11, 1365. [CrossRef]

21. Frączek, J.; Mudryk, K. Metoda pomiaru energochłonności procesu zrębkowania pędów wierzby. Inżynieria Rol. 2007, 7, 47-53.

22. Kronbergs, E. Mechanical strength testing of stalk materials and compacting Energy evaluation. Ind. Crops Prod. 2000, 11, 211-216. [CrossRef]

23. Stopa, R. Modelowanie Deformacji Korzenia Marchwi w Warunkach Obciążeń Skupionych Metoda Elementów Skończonych. Wydawnictwo Uniwersytetu Przyrodniczego we Wrocławiu: Frotswaff, Poland, 2010.

24. International Organization for Standardization. PN-EN ISO 148-1: 2017-02, Metals-Charpy Impact Test-Part 1: Test Method; ISO: Geneva, Switzerland, 2017.

25. Skubisz, G.; Rudko, T. Ocena właściwości mechanicznych wysuszonych łodyg i łuszczyn rzepaku. Rośl. Oleiste 1998, 20, 271-274.

26. Woliński, J.; Wolińska, J.; Kapela, K. Ocena energii łodyg gryki odmiany Hruszowska. Inż. Rol. 2005, 9, 179-184.

27. Prasada, J.; Gupta, C.P. Mechanical properties of maize stalk as related to harvesting. J. Agric. Eng. Res. 1975, 20,79-87. [CrossRef]

28. Lisowski, A.; Kostyra, K.; Chlebowski, J.; Klonowski, J. Opory cięcia łodyg w międzywęźlach i węzłach. Zesz. Probl. Postępów Nauk Rol. 2009, 543, 195-204.

29. Fraczek, J.; Mudryk, K.; Wróbel, M. Wybrane właściwości fizyczno-mechaniczne topinamburu (helianthus tuberosus L.). Inż. Rol. 2011, 15, 29-36. 
30. Chen, Y.; Gratton, J.L.; Liu, J. Power Requirements of Hemp Cutting and Conditioning. Biosyst. Eng. 2004, 87, 417-424. [CrossRef]

31. Chattopadhyay, P.S.; Pandey, K.P. Mechanical Properties of Sorghum Stalk in relations of Quasi-static Deformation. J. Agric. Eng. Res. 1999, 73, 199-206. [CrossRef]

32. Yore, M.W.; Jenkins, B.M.; Summers, D.M. Cutting Properties of Rice Straw. In Proceedings of the 2002 ASAE Annual International Meeting, CIGR XVth World Congress, Chicago, IL, USA, 28-31 July 2002.

33. Igathinathane, C.; Womac, A.R.; Sokhansanj, S. Corn stalk orientation effect on mechanical cutting. Biosyst. Eng. 2010, 107, 97-106. [CrossRef]

34. Azadbakht, M.; Esmaeilzadeh, E.; Esmaeili-Shayan, M. Energy consumption during impact cutting of canola stalk as a function of moisture content and cutting height. J. Saudi Agric. Sci. 2015, 14, 147-152. [CrossRef]

35. Nowakowski, T.; Lisowski, A.; Klonowski, J.; Gendek, A. Moduł sprężystości przy zginaniu łodyg wybranych roślin energetycznych. Zesz. Probl. Postępów Nauk Rol. 2009, 543, 229-237.

36. Mathanker, S.K.; Grift, T.E.; Hansen, A.C. Effect of blade oblique angle and cutting speed on cutting energy for energy cane stems. Biosyst. Eng. 2015, 133, 64-70. [CrossRef]

37. Venturi, P.; Gigler, J.K.; Huisman, W. Economical and technical comparison between herbaceous (Miscanthus $\times$ giganteus) and woody energy crops (Salix viminalis). Renew. Energy 1999, 16, 1023-1026. [CrossRef]

38. International Organization for Standardization. PN-EN ISO 18134-2:2017-03E, Solid Biofuels—Determination of Moisture Content_Drying Method_Part 2: Total Moisture—Simplified Method; ISO: Geneva, Switzerland, 2017.

39. International Organization for Standardization. PN-EN ISO 18125:2017-07, Solid Biofuels—Calorific Value Determination; ISO: Geneva, Switzerland, 2017.

40. Manzone, M.; Gioelli, F.; Balsari, P. Kiwi clear-cut: First evaluation of recovered biomass for energy production. Energies 2017, 10, 1837. [CrossRef]

41. International Organization for Standardization. PN ISO 1171:2010, Solid Mineral Fuels—Determination of Ash; ISO: Geneva, Switzerland, 2010.

42. International Organization for Standardization. PN-EN ISO 18123:2016-01, Solid Biofuels—Determination of Volatile Matter; ISO: Geneva, Switzerland, 2016.

43. International Organization for Standardization. PN-EN 310:1994, Fiberboard-Determination of Young's Modulus and Bending Strength; ISO: Geneva, Switzerland, 1994.

44. Vassilev, S.V.; Baxter, D.; Andersen, L.K.; Vassileva, C.G. An overview of the chemical composition of biomass. Fuel 2010, 89, 913-933. [CrossRef]

45. Lewandowski, I.; Clifton-Brown, J.; Andersson, B.; Basch, G.; Christian, D.; Jorgensen, U.; Jones, M.; Richie, A.; Schwarz, K.; Tayebi, K.; et al. Environment and Harvest Time Affects the Combustion Qualities of Miscanthus Genotypes. Agron. J. 2003, 95, 1274-1280. [CrossRef]

46. Tursunov, O.; Dobrowolski, J.; Zubek, K.; Czerski, G.; Grzywacz, P.; Dubert, F.; Lapczynska-Kordon, B.; Klima, K.; Handke, B. Kinetic study of the pyrolysis and gasification of Rosa multiflora and Miscanthus giganteus Biomasses via thermogravimetric analysis. Therm. Sci. 2018, 22, 3057-3071. [CrossRef]

47. Weger, J.; Hutla, P.; Bubeník, J. Yield and fuel characteristics tested for biomass production on agricultural soil. Res. Agric. Eng. 2016, 62, 155-161. [CrossRef]

48. Kaack, K.; Schwarz, K.U. Morphological and mechanical properties of Miscanthus in relation to harvesting, lodging, and growth conditions. Ind. Crops Prod. 2001, 14, 145-154. [CrossRef]

(C) 2019 by the authors. Licensee MDPI, Basel, Switzerland. This article is an open access article distributed under the terms and conditions of the Creative Commons Attribution (CC BY) license (http://creativecommons.org/licenses/by/4.0/). 